Wind Pressures Acting on the Roof and Wall Edges of a Low-Rise Building Part 4 Review of Previous Papers

植 松 康 ${ }^{* 1}$ ニコラス イシモフ ${ }^{* 2}$
Yasushi UEMATSU, Nicholas ISYUMOV

\title{
SUMMARY
}

Data gathered from a number of field and laboratory experiments concerned with the wind pressures acting on low-rise buildings are reviewed, and selected experimental results are presented in this paper. Particular attention is paid to works related to cladding design. Only either full-scale studies or those done under conditions simulating the atmospheric boundary layer have been considered. Comparison of the data from various sources, including code specifications, is made for the characteristics of the mean and fluctuating wind pressures.

The results indicate that the statistical properties of fluctuating pressures on the roof edge and corner regions can be predicted based on a quasi-steady approach. Furthermore, the peak factor approach is found to be useful for evaluating the peak pressures.

1. はじめに

本研究の目的は, 小規模な低首建築物の外装材設計用 風荷重の合理的な評価に必要な基䃊データを得ること にある。これまでは, ウェスタンオンタリオ大学の Boundary Layer Wind Tunnel Laboratory （BLWTL）で作成された切妻屋根低層建築物に作用す る風圧力に関するデータベースを利用して, 屋根や壁面 に作用する局部風圧の分布特性や変動特性を検討し た ${ }^{1)-3)}$ 。

低層建築物に作用する風圧力・風力に関しては, 1970
年代以降多くの実測や風洞実験が為されてきた。それ らの review が Stathopolos ${ }^{4)}$, Holmes ${ }^{5)}$, および, Krishna ${ }^{6)}$ によって為されているが, いずれも, その時 点までの研究によって得られた主な結果を取りまとめ た総括的なものである。また, 各国規基準での風荷重規 定值の比较が Kasperski ${ }^{7)}$ によって与えられている。

多くの建築物はいわゆる「低首建築物」という範睛に 属し, 形状や周辺状況は様々である。これまで多くの研 究が為されているとはいえ，低首建築物がもっている多 様性をカバーできるほどではない。これまでの研究で

* 1 東北大学大学院工学研究科都市・建築学専攻 助教授 工博

Assoc. Professor, Dept. of Architecture and Building Science, Tohoku Univ., Dr. Eng.

*2 ウェスタンオンタリオ大学BLWTL 教授 Ph.D.

Professor, Boundary Layer Wind Tunnel Laboratory, Univ. of Western Ontario, Ph.D. (原稿受理 : 平成 10 年9月 10 日) 
は，最も基本的かつ一般的な屋根形状である切妻屋根お よび陸屋根（勾配0の切妻屋根と考えることもできる） を対象としているものが多い。

1991 年台風 19 号による住宅被害の調查結果 ${ }^{8)}$ によれ ば, 被害の大半は屋根に生じており, 更にその多くが屋 根亘材の剥離や飛散である。屋根亘材の飛散は，それだ けの被害に止まらず, より大きな構造被害の原因となっ たり, 他の構造物の被害や人的被害など二次的被害を誘 発することもある。さらに, 屋根被害を受けると, 雨水 の侵入により家財の被害を引き起こし, 被害额が拡大す $3^{9)}$ 。従って, 低首建築物の設計においては, 屋根毒材 の耐風性に注意を払うことが肝要である。

以上の観点に立って, 本研究では, 屋根の端部や隅角 部に作用する局部風圧に着目し、これまで多くの実鬊が 為されている切妻屋根 (陸屋根を含む) を中心に, 既往 の実験データを解析し, 簡便で合理的な外装材設計用風 荷重の評価方法について考察する。但しここで外装材 とは, 風圧力を直接受ける仕上材だけではなく，母屋, 同縁, 間柱などの下地材も含む。

\section{2. 既往の研究概要}

ここで「低首建築物」とは, 屋根平均高さ $H$ が $20 \sim 30 \mathrm{~m}$ 程度までで, 建物幅 $B$ か $2 H$ 程度以上のものを指す。本 研究では, 1970 年代から現在までの 20 数年間に発表さ れた低首建築物の風荷重に関する詥文200数編を収集・ 整理してデータベースを作成した。主な出典は以下の 通りである。

1) J. Wind Eng. Ind. Aerodyn.

2) Proc. Int. Conf. on Wind Engineering

3 ）日本風工学会誌 (J. Wind Eng., JAWE)

既往の研究は, (1)自然風中での風圧・風力等の実湖, (2)風洞実験による風圧・風力等の湖定, (3)適切な風洞実 硂法の検討, (4)設計荷重の評価方法に分類できる。

高首建築物など大規模構造物に比べると, 自然風中で の実測が多く為されているのが特徽である。これは, 実 測そのものが比較的容易であるということもその一因 であろうが, 逆に風洞実験が非常に難しいということに も起因している。通常の境界首風洞において得られる 乱流境界層の幾何学的縮尺率は $1 / 200 \sim 1 / 500$ 程度の ものが多く，この縮尺率に合せると建物模型が非常に小 さくなってしまい, 詳細な風圧測定が困讙となる。さら に, 小規模構造物の場合, 接地境界首に埋没するため, 非常に複雑な性質を示す接地境界首を風洞内に適切に
再現しなければならないという難しさがある。

有名な実測建物としては，以下の3つが挙げられよう。 これらを用いた実测的研究は, 接地境界層や建物に作用 する風圧力の性状を理解する上で, また, 適切な風洞実 段手法を確立する上で, 風工学研究に大きく貢献した。 (1) Aylesbury の実殹建物（イギリス） 101,11)

平面形 $B \times L=7 \mathrm{~m} \times 13.3 \mathrm{~m}$, 㐿高 $h=5 \mathrm{~m}$ 。切妻屋 根の勾配 $\beta$ を $5^{\circ}$ から $45^{\circ}$ の螌囲で自由に設定可能。 世界中から 17 の研究機関が参加して比較風洞実験 ${ }^{12)}$ が 行われ，低屏建築物に対する妥当な風洞実験手法につい て様々な角度から議詥された。実測結果との比較によ り, 相似条件として, Jensen 数 $H / z_{0}$ ( $z_{0}$ は地表面の粗 度長) だけでは不十分であり, 上流側の局所的な粗度要 秦（樹木や生け垣等）や接近流の風速変動の無次元パ ワースペクトルを適切にモデル化することの必要性が

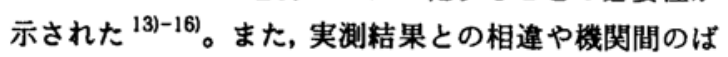
らつきの主要因は, 基準静圧および基準速度圧の設定方 法にあることも指摘された ${ }^{12), 16)-19) 。 ~}$

(2) Silsoe Structures Building (イキリス) 20)

平面形 $B \times L=12.93 \mathrm{~m} \times 24.13 \mathrm{~m}$, 軒高 $h=4.14 \mathrm{~m}$, 切妻屋根勾眍 $\beta=10^{\circ}$ の鉄骨フレーム構造。軒形状は 鋭角と曲線の二種類。中央断面内や屋根端部の風圧力, 鉄骨フレームや慗ぎ梁の歪等が精度よく測定され，風洞 実鍂や数值シミュレーション手法を検討する上でのべ ンチマークとなる結果が提供されている ${ }^{201-30) 。 ま た ， ~}$ 実测結果に基つきき, 設計用風荷重評価における準定常ア プローチの適用性が検討された ${ }^{31)-37)}$ (4.1節参照)。

(3) TTU Building (アメリカ) ${ }^{38)-40 \text { ) }}$

平面形 $B \times L=9.1 \mathrm{~m} \times 13.7 \mathrm{~m}$, 軒高 $h=4.0 \mathrm{~m}$, 陸屋 根鉄骨フレーム構造（実祭には $1 / 60$ の勾配がついてい ろが, 水勾配程度であるから,ここでは陸屋根と見なす)。 建物全体が円形レールの上に载っており，回転すること によって相対的な風向角を自由に設定可能。測定され た風速, 風圧デー夕は精度や定常性の検定を経た後デー タベース化されて提供されており, 各種解析に利用され

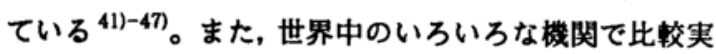

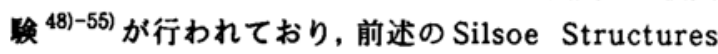
Building と同様, 妥当な風洞実験手法の確立に大きく 貢献している。

今回筆者らが収集した既往の文献で対象としている建 物を屋根形状別に見てみると, 上記 3 建物に関する論文 が多いということもあって, 約 $50 \%$ が切妻屋根, 約 40 \%が陸屋根である。その他の形状, 例えば, 寄棟屋根や 
片流れ屋根に関する詥文は非常に少ない。これは, 住宅 等小規模な建物を除けば, 切妻屋根や陸屋根が最も基本 的な形状であるということによる。従って, 本詥文でも 必然的にこれらの屋根が主な対象となる。

また，数編を除きほとんど全てが単独建物（単体モ テル）を扱っている。これは，低首建筑物では同程度か それ以上の大きさの建物に囲まれて建つことが多く，そ のような場合には単独で建つ場合より風荷重が一般に 低減するため, 設計荷重としては単体モデルの值を用い ておけば安全側の設定になるという考えに依っている。 周辺建物が風荷重に及ぼす影管に関連し, Ho ${ }^{56)-58)}$ は さまさまな市街地モデルの中に置かれた陸屋根低首建 筑物に作用する風圧力を溂定し, 周辺状況に起因する風 圧力のばらつきを詀べた。その結果によれば, 大きな建 物が接近して建つような埸合を除けば, 単体モデルのピー ク風圧力は, 種々の地域モデルに対する值のうちの最大 值にほぼ相当している。但し, 周辺状況によって風圧力 のピーク值は大きくばらつき, その変軼係数は $0.6 \sim 0.8$ 程度にまで達する。このような結果を受け, 彼らは単純 な平均值や最大值ではなく，ばらつきを考虚した設計荷 重設定の必要性を主張している。しかし, 現時点におい ては, 無数に存在する周辺状況に対して, その影篦を定 量的に議詥できるほどデー夕は蓄積されていないので, 本詥文では単体モデルを対象とする。

\section{3. 平均風圧力の特性}

多くの国の設計規基準における風荷重算定法は準定常 的な考え方に依っている。この場合，平均風圧係数が算 定の基本となる。そこで, 先ず屋根端部や隅角部領域の 平均風圧係数（特に負圧）について見てみる。Fig. 1 は本詥文で用いる記号および領域の定義を表わす。な お,ここでは建物の対称性を考虑し, 風向角の籍囲は $0^{\circ} \sim 90^{\circ}$ とする。また, 四中の $l^{\prime}$ は, 建築物荷重指針 ${ }^{59}$ （以後「荷重指針」と呼ぶ）と同様, $l^{\prime}=\min (2 H, B)$ である。

建物周りのフローパターンは, 屋根勾配 $\beta$ および風向 角 $\theta$ によって大きく変化し, それに対応して平均風圧係 数も变化する。Fig. 2 は, 既往の実験デー夕 ${ }^{60)-68)}$ に基 ゔき, 屋根面上で最大負圧の発生する領域を $(\beta, \theta)-$ 平面上に示したものである。これより明らかなように, 最大負圧を与える位置は $\beta$ と $\theta$ によって変化する。 $\theta \approx 0^{\circ}$ の場合, $\beta$ が增大すると流れの剥離によって生 じる風上屋根端部の負圧は次第に小さくなる。また， $\beta$ が一定值を超えると風上端での流れの剥離は生じなく なり, 棟位固で剥麇するようになる。このような流れの 变化に伴い，最大負圧の発生位置は， $\beta \approx 18^{\circ}$ で領域 $\mathrm{A}$ から領域 $\mathrm{E}$ に変化する。建物に対して斜めに風が当た 万場合 $\left(\theta \approx 20^{\circ} \sim 70^{\circ}\right), \beta$ が比較的小さい時には $\left(\beta<18^{\circ}\right)$, いわゆる「円錐渦」が生成されるため, 屋 根隅角部 (領域B) に局所的ではあるが非常に大きな負 圧が作用する。 $\beta$ が $22^{\circ} \sim 23^{\circ}$ より大きくなると, $\theta<45^{\circ}$ では風下屋根の棟近傍（領域 $\mathrm{E}$ ), $\theta>45^{\circ}$ で は屋根風上端部（領域C）に最大負圧が発生する。 $\beta$ が $20^{\circ}$ 前後の時, $\theta \approx 15^{\circ} \sim 45^{\circ}$ では領城 Dに大きな負 圧が作用する。前報 ${ }^{3)}$ で述べたように, $\beta=18^{\circ}$ の場 合, 領域Dに作用するピーク負圧は荷重指針值よりかな ク大きくなる。 $\theta$ が約 $70^{\circ}$ 以上と大きくなると， $\beta$ に 拘らず屋根風上端部（領域 C) に最大負圧が作用する。 これは, $\theta \approx 0^{\circ}$ で $\beta$ が小さい時と同様, 風上端での流 れの剥閏に起因している。

次に, 比較的実検デー夕の多い領域 A, B, Eについて, 各領域内での平均風圧係数の最小值 (最大負圧係数) を 既往の実験結果 201, 21), 261, 35), 41), 421, 48), 501, 63), 67)-71) よ り求め, $\beta$ に対してブロットしたものがFig. 3である。

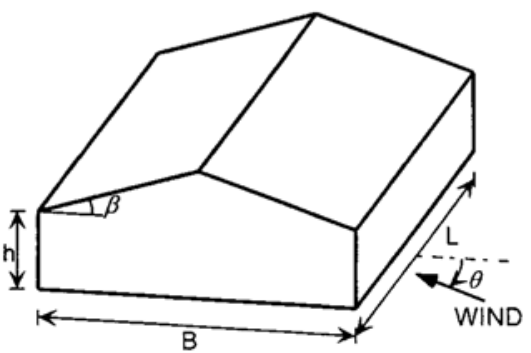

(a)

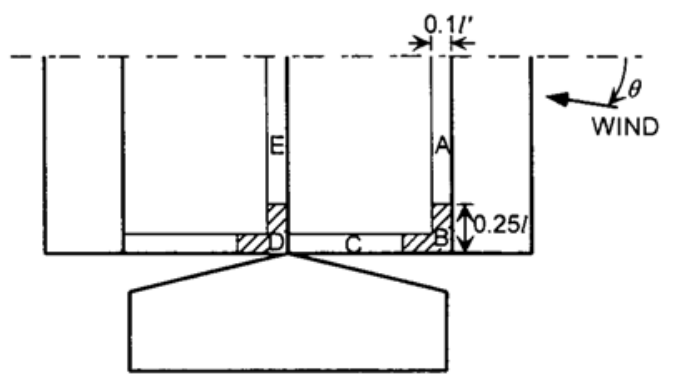

(b)

Fig. 1 記号および領域の定義

(Building dimensioning notation and definition of regions) 

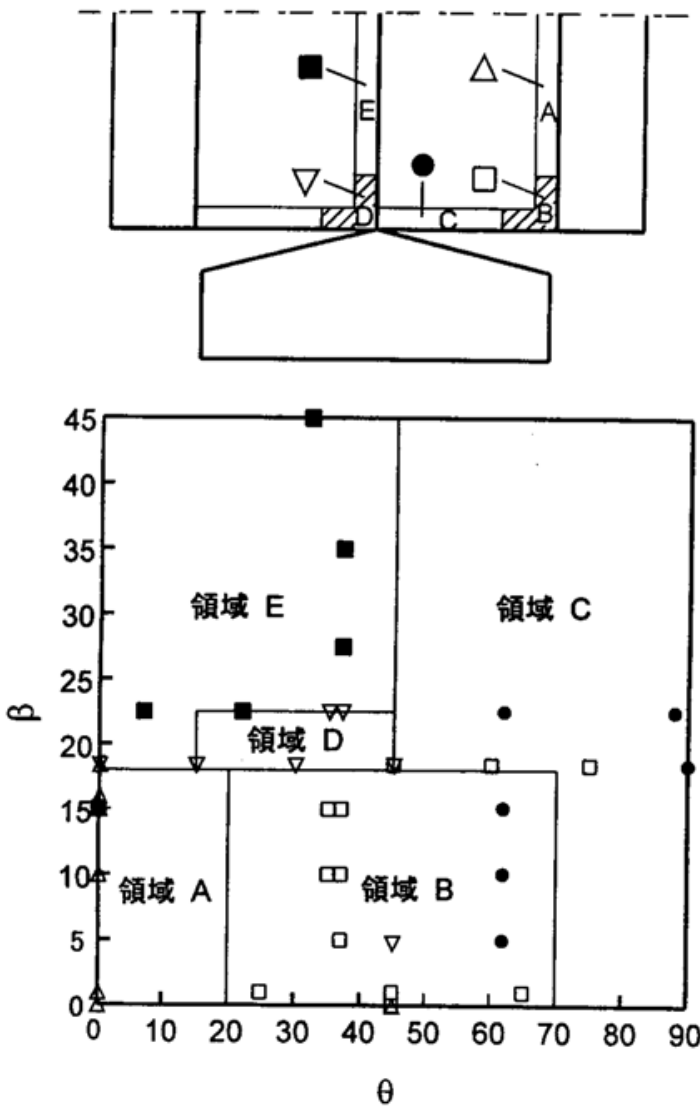

Fig. 2 屋根面上で最大負圧 (時間平均值) の発生 する領城

(Region of the maximum timeaveraged suction on the roof)

図中の実線は荷重指針值（但し, $L / H<6)$ を表してい る。なお, 領域 $\mathrm{E}$ の $\beta<10^{\circ}$ に対する值は $B / H$ に応じ てー0.8から- 1.0 まで変化するので 2 本の直線で表し た。実験デー夕を指針值と比較すると, 一般に, $\beta<20^{\circ}$ では実銩デー夕のばらつきが大きい（特に, $\beta \approx 0^{\circ}$ の

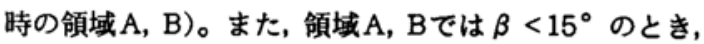
領域 $\mathrm{E}$ では $\beta \approx 10^{\circ} \sim 20^{\circ}$ の簀囲で, 実験值が指針值 を大きく上回っているケースも多い。

\section{4. 変動風圧力の特性}

4.1 準定常アプローチによる変動風圧力の評価

低層建築物の大半を占めるのは, 住宅, 倉庫, 工場な ど, 規模の比較的小さい建築物である。このような建築 物の場合,一般に剛性が高いので変動風荷重に対する共 振応答を考慮する必要はない。また，建物の代表寸法は 自然風中に含まれる瀜の平均的なスケールに比べて小 さいので, 準定常アプローチで骨組に作用する最大風荷
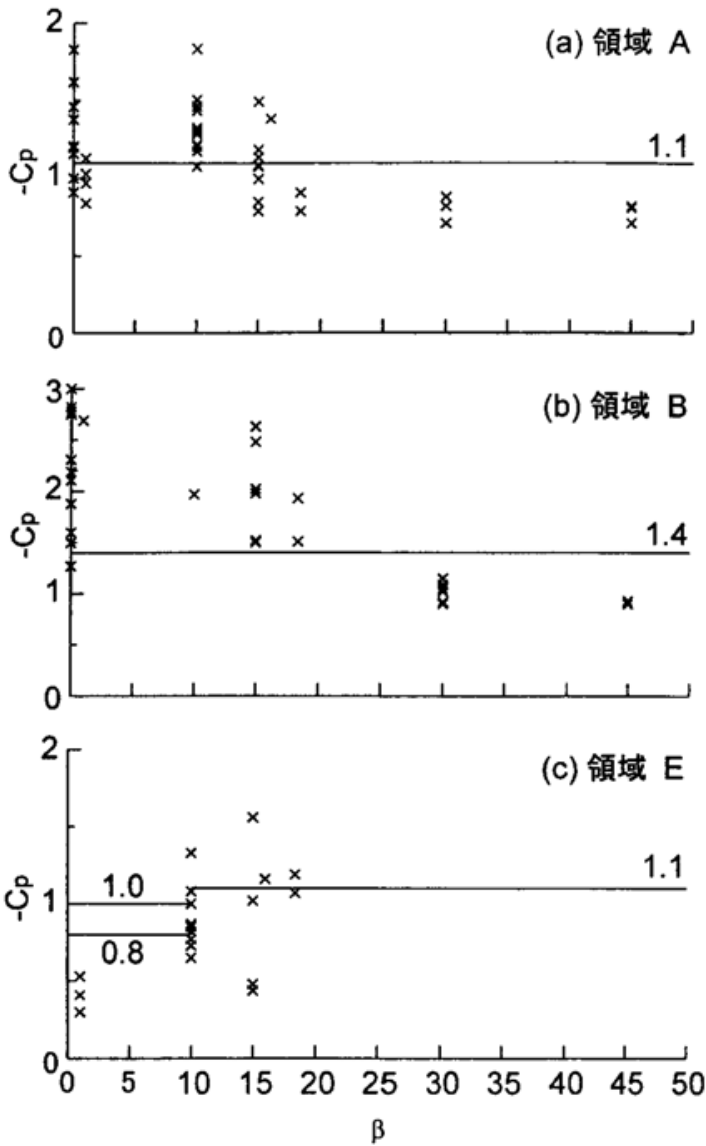

Fig. 3 領域 A, B, E内での最小風圧係数（時間平均值） の屋根勾配による变化

(Variation of the minimum pressure coefficient with roof pitch)

重を評価できることが多い。ここで, 準定常アプローチ とは, 風圧力が風速変動に追随して変化すると考えるも のである。最も簡単には, ピーク荷重は最大瞬間風速時 に発生すると考える。この場合, 最大瞬間速度圧に平均 風圧係数を乗じることによって設計用風荷重を見積も ることが可能となる。

準定常アプローチでは建物による渦の歪みや建物自身 によって生じる乱れの影篅は考虑されていないため, 厳 密には剥離領域における変動風圧力をこれによって求 めることはできない。剥離渦のスケールは,一般に接近 流に含まれる洞のスケールに比へて小さく，高周波数の 圧力変動を引き起こすため, 屋根苜材のように荷重負担 面積の小さい部材に対しては重要となる。一方, 下地材 のように荷重負担面積がある程度大きくなると,このよ うな小さいスケールの渦の作用は荷重負担領域内で相 殺されるため, 変動風圧力の荷重奻果を準定常アプロー 
チに基づいて評価することが可能となる。

準定常アプローチの説明並びに妥当性の検討は, Kawai ${ }^{72)}$, Letchhord ら ${ }^{43)}$, および, Hoxey ${ }^{33)-37) に ~}$ よって為されている。以下それらに基づき,この方法に ついて概説する。

風速变動には平均流方向成分 $u$ のほか, これに直角な 2 成分 $v$ (横方向) および $w$ (铅直方向) がある。低首 建築物を対象とすると， $w$ 成分は小さいと考えられる ので, 简単のため通常考虑されない。準定常アブローチ では, $u$ は風速の変化として, $v$ は風向の変化として扱 われ, 建物に作用する風圧力はその変化に従って変動す ると考える。すなわち, 各時刻 $t$ の風圧力 $p(t)$ は, その 時点での瞬間的な風向の一様流が吹いている時の平均 風圧力に等しいと考元, 次式で与えられるものとする。

$$
p(t)=q(t) \cdot C_{p}(\theta(t))=\frac{1}{2} \rho V^{2}(t) \cdot C_{p}(\theta(t))
$$

ここで, $\rho$ は空気密度, $V(t)$ は時刻 $t$ における風速, $C_{p}(\theta(t))$ は時刻 $t$ における風向角 $\theta(t)$ に対する平均風 圧係数である。

いま, 最大瞬間風速時に最大ピーク風圧が発生し, 風 向变動の影裙が小さいと仮定すれば, ピーク風圧係数 $\hat{C}_{p}$ は次式で与えられる。

$$
\hat{C}_{p} \approx G_{v}^{2} C_{p}(\bar{\theta})
$$

ここで, $G_{v}$ は接近流のガストファクターを, $\bar{\theta}$ は平均風 向を表す。

次に, 風向变動の影辨も考えてみる。(1) 式の $V(t)$ は平均風速 $U$ (風向 $\bar{\theta})$ および $u, v$ を用いて,

$$
V^{2}(t)=(U+u)^{2}+v^{2}
$$

横方向の風速変動 $v$ は水平面内の風向変動 $\theta^{\prime}$ に置き換 えることができ，

$$
\theta^{\prime}=\tan ^{-1}\left(\frac{v}{U+u}\right)
$$

次に, 変動風速成分は $U$ に比べて小さいし, 2 次以上 の微小項を無視（線形化）すると，

$$
C_{D}(\theta(t)) \approx C_{p}(\bar{\theta})+\left.(\theta(t)-\bar{\theta}) \frac{d C_{p}}{d \theta}\right|_{\theta=\bar{\theta}}
$$

あるいは, (4) 式を用いて書き改めると,

$$
C_{p}(\theta(t)) \approx C_{p}(\bar{\theta})+\left.\left(\frac{v}{U}\right) \frac{d C_{p}}{d \theta}\right|_{\theta=\bar{\theta}}
$$

（3)，(6) 式を（1）式に代入して整理すると，時刻 $t に$ おける風圧係数として次式を得る。

$$
C_{p}(t)=\frac{p(t)}{\frac{1}{2} \rho U^{2}} \approx\left(1+\frac{2 u}{U}\right) C_{p}(\bar{\theta})+\left.\left(\frac{v}{U}\right) \frac{d C_{p}}{d \theta}\right|_{\theta=\bar{\theta}}
$$

これより,u、vが互いに独立であるとすると, $\mathrm{rms}$ 変動 風圧係数 $C_{p}$ 'は以下のように与えられる。

$$
\begin{aligned}
C_{D}^{\prime} & \approx\left[\left(2 \frac{\sigma_{u}}{U} C_{p}(\bar{\theta})\right)^{2}+\left(\left.\frac{\sigma_{v}}{U} \frac{d C_{p}}{d \theta}\right|_{\theta=\bar{\theta}}\right)^{2}\right]^{1 / 2} \\
& \approx\left[\left(2 I_{u} C_{p}(\bar{\theta})\right)^{2}+\left(\left.I_{v} \frac{d C_{p}}{d \theta}\right|_{\theta=\bar{\theta}}\right)^{2}\right]^{1 / 2}
\end{aligned}
$$

ここで, $\sigma_{u}, \sigma_{v}$ および $I_{u}, I_{v}$ は風速変動 $u, v$ rms值お よび乱れの強さを表す。さらに, $u$ に比へてvが小さい 場合，または， $C_{p}$ の風向変化が小さい場合には，以下の ように簡単になる。

$$
C_{p}^{\prime} \approx 2 I_{u} C_{p}(\bar{\theta})
$$

いま, $u, v$ の確率密度関数が正規分布であるとすると， (7) 式より $C_{p}(t)$ の確率密度関数も正規分布になる。ま た, $p(t)$ のパワースペクトルは $u$ およびvのパワース ペクトルの線形和で表される。

以上示した各種関係式の妥当性や適用性を, 既往の風 洞実験や実測結果との比較により検討してみる。先ず, Stathopoulos $5^{74)}$ は, 勾配 1: 12 の切妻屋根低層建築 物モデル $(B \times L=24.4 \mathrm{~m} \times 30.5 \mathrm{~m}, h=4.9 \mathrm{~m}$, 以後 「UWO1 : 12 勾配モデル」と呼ふ）に関する風洞実験結 果より, $\theta=0^{\circ}$ p $90^{\circ}$ の場合, 風上壁面や屋根風上端 部においては（9）式が概ね成り立つが, wake内の領 域では（9）式による推定值と実験值の一致度が悪いこ とを示した。同様の結果か, TTU Buildingを対象と したOkada \& $\mathrm{Ha}^{50)}$ の風洞実験によっても示されてい る。一方, 風が斜め方向から吹く場合の屋根妫角部につ いては,必ずしも一致した結果は得られていない。 $\mathrm{Kind}^{62), 75)}$ は, 陸屋根を対象として風洞実呀を行い, $G_{v}=1+3 I_{u H}$ (ただし, $I_{u H}$ は高さ $H$ における乱れの強さ) とおくと（2）式によりピーク風圧係数を概ね妥当に評 価できるとしている。一方, Milford \& Waldeck ${ }^{76)}$ はJun Smuts 空港格納庫 (平面形 $100 \mathrm{~m} \times 150 \mathrm{~m}$, 軒 高 $30 \mathrm{~m}$ ) の屋根隅角部に作用する風圧力の実湖を行い, 風圧力のガスト影䈏係数が $G_{v}^{2}$ よりかなり大きくなるこ とを示した。また, Letchford ら ${ }^{43)}$ は, TTU Building での実測結果と準定常アブローチによる結果を比較し 
た (Fig. 4参照)。それによれば, 円錐渦が発生する場 合, その下の領域では, Fig. 4 (b) に示すように, 準定 常アプローチは実測值に対して過小評価となっている。 このような相荤が発生した理由は従来建物自身によっ て生成される渦の影䉕であると考えられてきた。しか し, 最近Tieleman ${ }^{77)}$ は, 接近流に含まれる small-scale turbulenceが剥崔せん断層の挙動に大きな影霎を及ぼ すことを示し, 準定常アプローチではこの影督を考虑し ていないことが相䕗の原因であると主張している。ま た, Hoxey ら ${ }^{33)-37)}$ は，(5) 式（または（6）式）で行 った線形化に問題があるとして, 新たな理詥を展開した。 それによれば, rms変動風圧係数は最終的に次式で与え られる。

$$
\begin{aligned}
& \left(C_{p}^{\prime}\right)^{2}=\frac{(p-\bar{p})^{2}}{\bar{q}^{2}}=\left[C_{p}(\bar{\theta})\right]^{2} \frac{\sigma_{q}^{2}}{\bar{q}^{2}}+\sigma_{C p}^{2}\left(1+\frac{\sigma_{q}^{2}}{\bar{q}^{2}}\right) \\
& \sigma_{C p}^{2}=\overline{\left[C_{p}(\theta)-C_{p}(\bar{\theta})\right]^{2}}
\end{aligned}
$$

ここで, $\bar{q}, \sigma_{q}$ は速度圧の平均值と標準伺差であり, 風向 $\theta$ は正规分布に従うとしている。彼らは, Silsoe Structures Buildingにおける実測結果と上式による 結果を比较し, 屋根端部や隅角部の测定点に対しても両 者が比较的よく一致することを示した。一方, 屋根中央 部分においては, 実測值が上式による結果より一般に大 きくなっている。これは準定常アプローチの限界を示 すものであるが,このような領域ではピーク風圧自体が 小さいため, 設計上それほど重要な問題にはならない。

変動風圧力の礁率密度関数についてもいくつかの研究 が為されている。低層建築物の場合, 流れの剥䧹の影零 を受ける負圧領域だけではなく，風上壁面の正圧領域に おいても，確率密度関数が正規分布からずれることが多 ( 4), 43), 78), 79)。これは, 地表付近では風速变偊が大きく なるため非線形効果が現れたものと考えられ, Kawai ${ }^{72)}$ およびHolmes ${ }^{79)}$ は風速変動 $u$ の非線形項を考墟する ことによって実検結果との一致度が改善されることを 示した。しかし, 陸屋根隅角部のように風向変動の影整 を強く受ける領城では，確率密度関数の裙野での不一致 は依然として大きい" ${ }^{43)}$ (Fig. 4 (c))。Stathopoulos ${ }^{78)}$ は, UWO1：12勾配モデルを用いた風洞実䀫結果を解 析し, 実用上重要となる高風圧レベルに対して変動風圧 の確率分布がワィブル分布で良好に近倾できることを 示しだ。ワイブルパラメータ (尺度母数 $C$, 形状母数 $k$ ) を種々のケースについて求めたところ, 正圧域では気流

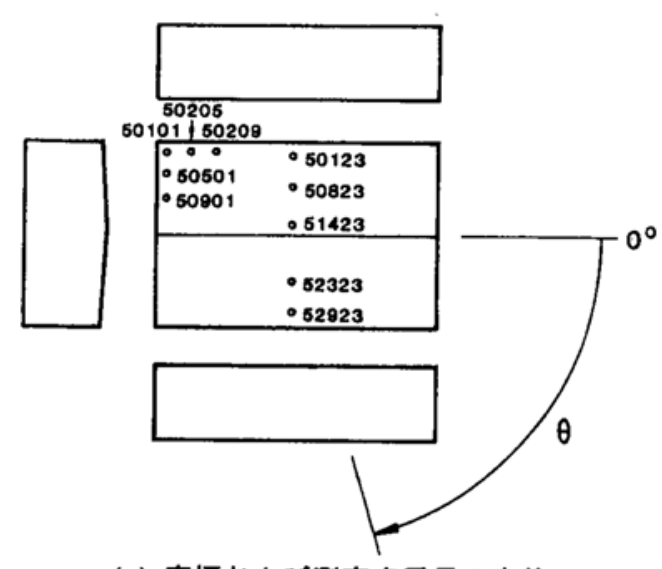

(a) 座標および測定点番号の定義

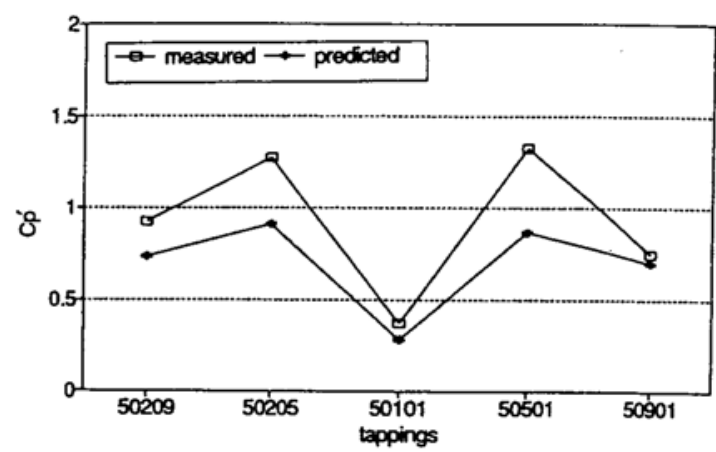

(b) $r \mathrm{~ms}$ 变動風圧係数 $\left(\theta=228^{\circ}\right)$

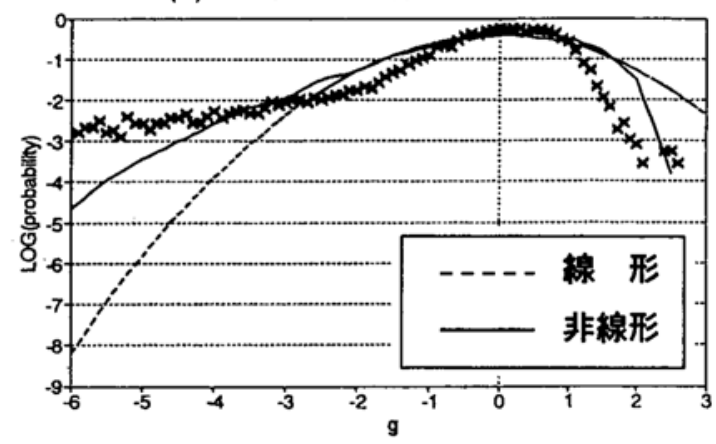

(c) 確率密度関数 (測定孔 50101， $\theta=228^{\circ}$ )

Fig. 4 TTU Building での実測結果と準定常アプロー チによる結果との比较 ${ }^{43)}$

(Comparison between field measurement and quasi-steady approach ${ }^{43)}$ )

特性や測定点位圆によらず, $C \approx 0.85, k \approx 1.10$ である が, 負圧域では気流特性や測定点位置によって, $C=0.50$ $\sim 0.65, k=0.95 \sim 1.20$ の䉳囲にあった。

\section{2 ピーク風圧力の評価}

（1）ピーク風圧力の評価方法について

ピーク風圧力の評価方法としてよく用いられるものに, 
上述の準定常アプローチのほか, ピークファクター法, およびCook \& Mayneの方法 ${ }^{801,81)}$ がある。ピーク 風圧係数 $\hat{C}_{p}$ は, 準定常アプローチでは (2) 式で与えら れる。一方, ピークファクター法では, ピークファクター $g$ および $\mathrm{rms}$ 変動風圧係数 $C_{p}{ }^{\prime}$ を用いて,

$$
\hat{C}_{p} \approx C_{p} \pm g \cdot C_{p}{ }^{\prime}
$$

ここで, ガスト成分 $g \cdot C_{p}$ ' の符号は, $C_{p}$ の符号によっ て絶対值がきくなる方を異ぶ。Cook \& Mayneの 方法は, 風速および風圧力の極值分布に基づいて設計用 風圧力 $C_{p}^{*}$ を確率・統計的に求めるものであり, 簡便式 は以下のようである。

$$
C_{p}^{*}=U_{C p}+1.4 / a_{C p}
$$

ここで, $U_{C D}$ および $1 / a_{C D}$ は, ピーク風圧係数の確率分 布をFisher-Typpettの I 型極值分布で表した時のmode およびdispersionであり,これらは風洞実鸦によって 求められる。

$\mathrm{Cook}^{82)}$ は, 代表的な 6 種類の建物モデルを用い, 上記 3 種類の方法によって定まるピーク風圧係数の間の関係 を検討した。そのうち, UWO1 : 12 勾配モデルに関す る結果をTable 1にまとめて示す。ここで, $R_{1}$ および $\varepsilon_{1}$ は， $C_{p}^{*}$ と $C_{p}$ の関係をプロットしたときの相関係数 と回㷌直線からの実検データのばらつき（標準偏差）を 表している。また, ピークファクター $g$ は, $\hat{C}_{p}=C_{p}^{*}$ とおいて算定した。表中の $\bar{g} と \sigma_{g}$ は検討した全測定点 および全風向に対する結果の平均值と標準局差である。 $a, R_{2}$ ，および $\varepsilon_{2}$ は， $C_{p}^{*}$ と $\hat{C}_{p}(\bar{g}$ を用いて (12) 式 より計算される值) の関係をブロットしたときの回㛿 係数, 相関係数および実験デー夕の回㷌直線からのばら つき(標準偏差) である。

準定常アプローチでは, $C_{p}^{*} / C_{p}$ の值は $G_{v}^{2}$ に一致す ることになるか, Table 1の結果によれば, 実眕結果は $G_{v}^{2}$ より多少小さな值を示している。 $C_{p}^{*}$ と $C_{p}$ の相関 はよいが (相関係数 $0.95 \sim 0.98), \varepsilon_{1}$ の值からも分かる ように, データのばらつきは大きい（特に, ガストの評 価時間が短(場合)。一方, ピークファクター法による $\hat{C}_{p}$ は, $a \approx 1$ であることより, 平均的には $C_{p}^{*}$ にほぼ 一致している。また, データのばらつきも準定常アプロー チによる結果の $1 / 2$ 以下と小さい。従って, $g$ の值を適 切に定めることができれば, ピークファクター法はピー ク風圧の予測に対して有奻であろう。

母屋, 同緑などの下地材への荷重奻果を考える埸合に は, 各点に作用する風圧力ではなく, ある程度の算囲に
Table 1 UWO1：12勾配モデル作用するピーク風圧力 に対する準定常アプローチ, ピークファクター法 とCook \& Mayneの方法による結果の比較 (文 献 [82] の䊅果に基づき作成)

(Calibration of the quasi-steady and peak factor approaches to the assessment of wind loads against Method of Cook and

\begin{tabular}{|c|c|c|c|c|}
\hline 方 法 & 检封愐目 & $\begin{array}{c}\text { Class A } \\
(1 \text { 秒ガスト) }\end{array}$ & $\begin{array}{c}\text { Class B } \\
(4 \text { 秒カスト })\end{array}$ & $\begin{array}{c}\text { Class C } \\
(16 \text { 秒カスト })\end{array}$ \\
\hline \multirow{4}{*}{ 定常フプローチ } & $C_{p}^{*} / C_{p}$ & 2.56 & 2.16 & 1.75 \\
\hline & $G_{v}^{2}$ & 2.88 & 2.38 & 1.94 \\
\hline & $R_{1}$ & 0.951 & 0.966 & 0.981 \\
\hline & $\varepsilon_{1}$ & 0.34 & 0.24 & 0.14 \\
\hline \multirow{5}{*}{ ビークファクター法 } & $\bar{g}$ & 5.42 & 4.74 & 4.31 \\
\hline & $\sigma_{g}$ & 1.13 & 0.83 & 0.70 \\
\hline & $a$ & 0.981 & 0.981 & 0.957 \\
\hline & $R_{2}$ & 0.989 & 0.993 & 0.996 \\
\hline & $\varepsilon_{2}$ & 0.16 & 0.10 & 0.06 \\
\hline
\end{tabular}
Mayne)

対する面平均風圧力が問題となる。面平均風圧力は多 くの点に作用する風圧力の集積であるから, 面積が広く なるほどその確率密度関数は正規分布に近づく（中心 極限定理)。以下の (3) に述へるように, ピーク風圧に

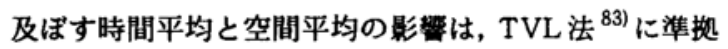
した方法により互いに関連づけられる。また, Table 1 に示した結果より, ガストの評価時間が長くなると, $\varepsilon_{1}$ および $\varepsilon_{2}$ の值が小さくなることより, 上記 3 種類の 方法によって算定されたピーク風圧係数の一致度が良 好になることが分かる。従って, 面平均された風圧力 (お るいは, その結果としての部材応力など）のピーク值を 準定常アプローチに基づいて推定することが可能にな ると考えられる。先に示したMilford \& Waldeck ${ }^{76)}$ によるJun Smuts空港格納庫での実測結果によれば, 屋根䧓角部の約 $5 \mathrm{~m} \times 5 \mathrm{~m}$ の領域に対する面平均風圧力 は概ね正規分布に従い,ピーク值も（2）式による結果 にほぼ一致している。なお,この実測では， $G_{v}$ は風速 記録から直接求められており, ガストの評価時間は明確 に示されていないが, 使用された風速計の応答性から判 断すると, 評価時間は2〜3秒程度であると考えられる。 さらに, Robertson ${ }^{32)}$ はSilsoe Structures Building の中央フレームおよびつなぎ梁（長さ約 $4 \mathrm{~m}$ ) の歪を測 定し, 以下のような結果を得た。

1) 歪のピーク值については, ピークの評価時間 $t$ が 1 秒以下のとき，評価時間がピーク值に及ぼす影篦は ほとんどない。従って, 歪や応力に対するピークの 評価時間としては 1 秒程度を考えればよい。 2 ) 歪の 1 秒ピーク值に相当するガストの評価時間, す 
なわち, 歪の 1 秒ピーク值が $G_{v}^{2} \times$ (時間平均值) に等しいとおいた時の $G_{v}$ の評価時間は, 主要骨組 については5〜6秒, 二次部材については約2秒で ある。ただし, 二次部材については, その位置によ って評価時間は多少変わる。

\section{(2) ピークファクターについて}

筆者らは, ピークファクター $g$ と最小風圧係数 $C_{P, \min }$

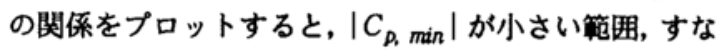
わち屋根や壁面の中央部では $g$ の值が大きくばらつく が, $\left|C_{p, \text { min }}\right|$ が增大するとばらつきが次第に小さくなり, 局部風圧領域に着目すると, 屋根面では $g \approx 6$, 壁面で は $g \approx 7$ となることを示した ${ }^{2)}$ 。しかし, 扱った屋根勾 配は $4: 12$ の 種類のみであったため,ここでは様々な 屋根勾配 $\left(5^{\circ} \sim 22.5^{\circ}\right)$ に対する既往の実硂結果 ${ }^{10), 76)}$ を用いて同様の検郡を行った。結果をFig. 5 に示す。定 性的には勿詥, 定量的にも筆者らが先に行った実験結果 と同様の頓向を示している。また, TTU Buildingに 関する実測 ${ }^{41)}$ および風洞実験結果 ${ }^{50)}$ によれば, $\theta=0^{\circ}$ の場合, 屋根面負圧のピークファクターは 4 7 の範囲 にあり, 上の結果と概ね一致している。

次に, Fig. 6はピークファクターに及ぼす移動平均時 間 $T_{a}$ の影鳘について，筆者らの結果 ${ }^{2)}$ をTU Building における実測結果 ${ }^{41)}$ と共に示したものである。なお, TTU Building での実測においては, $T_{a} \rightarrow 0 \mathrm{sec} に$ 対 する $g$ の值が不明であったため, 筆者らによる実験公式 を用いて $T_{a}=0.1 \mathrm{sec}$ の值より推定した。Fig. 6 を見 ると, いずれの結果も, $g$ が $T_{a}$ の增大に伴って低下す ることが分かる。ただし, TTU Buildingの方が低下 する割合かいくらか大きい。

（3）最小風圧係数に及ぼす時間平均と空間平均の奻果 建築物に作用する外圧は，一般に空間的にも時間的に も複雑に変化する。本研究「その1」 ${ }^{1)}$ では, 屋根や壁 面端部に作用する非常に大きな負圧の広がりは, $1 \mathrm{~m} \times$ $2 \mathrm{~m}$ 程度, 継続時間も $0.2 \sim 0.3$ 秒程度であり, 最小風圧 係数の大きさが時間平均や空間平均 (面平均) 操作に よってかなり低下することを示した。また,「その3」 ${ }^{3)}$ では, 風洞実験結果に基づき, 最小風圧係数に及ぼす時 間平均 (移動平均) と空間平均の効果について検討し, 移動平均時間 $T_{a}$ と空間平均を行う領域の面積 $A$ とが 次の関係で結ばれていることを示した。

$$
\sqrt{A}=\frac{T_{a} \cdot U_{H}}{k_{p}}\left(=l_{T a}^{*}\right)
$$
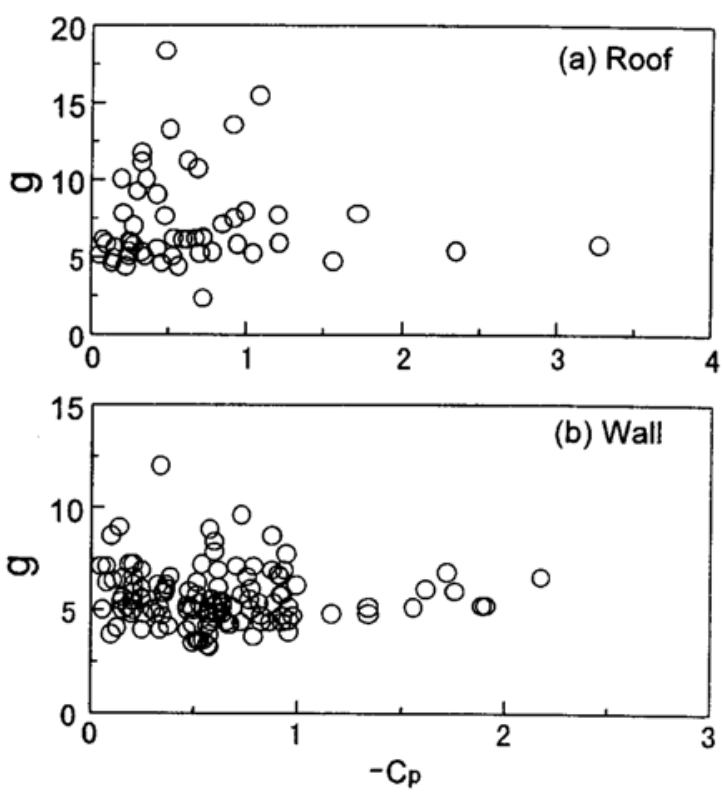

Fig. 5 ピークファクターと平均風圧係数の関係 (Relation between the peak factor and the mean pressure coefficient)

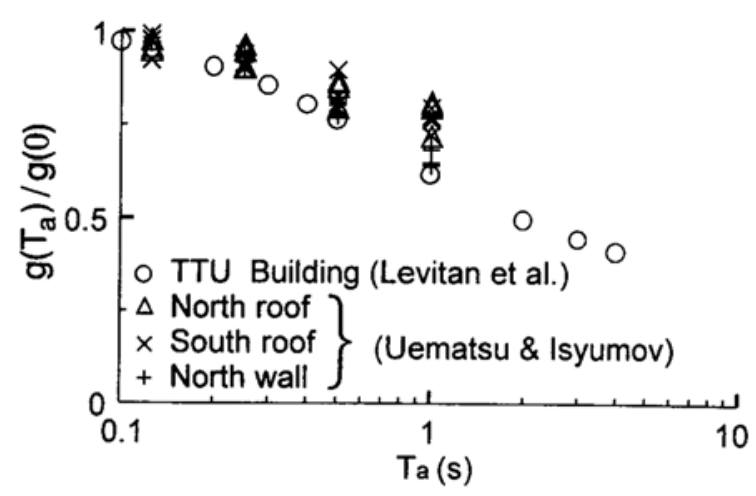

Fig. 6 ピークファクターに及ぼす移動平均の影警 (Effect of moving averaging time on the peak factor)

ここで, $U_{H}$ は基準高さ $H$ における風速, $k_{p}$ は各領域に おける变動風圧力のルートコヒーレンスを指数関数で 近似した時のディケイ・ファクターである。Fig. 7 は, 本研究でこれまで対象とした低首建築モデルのパネル 1, 3, 5 (「その1」のFig. 2参照) 内の最小風圧係数 $C_{p, \min }$ に及ぼす $T_{a}$ の影篅, 並びに, 各パネル領域内での面平 均風圧力の最小值 $C_{p, \min }$ に及ぼす $A$ の影響を表してい る。図中○旫は $C_{\mathrm{p}, \min }\left(T_{a}\right) / C_{p, \min }(0)$ と $l_{T a}^{*}$ の関係をプ ロットしたもの, I 印は $C_{p, \min }(0) / C_{p, \min }(0)$ と $\sqrt{A}$ の 関係を実蜍データのばらつきを考虑して表したもので ある。実硂の範囲は限られているが, 両者はよく対応し 


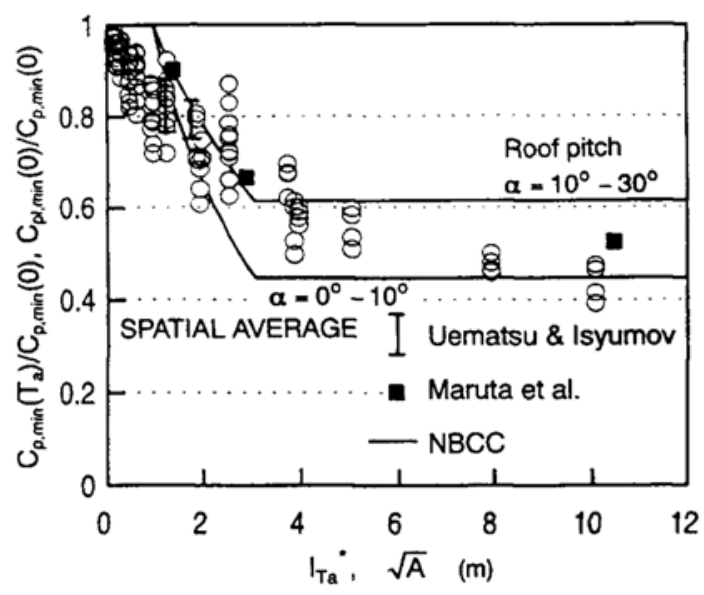

Fig. 7 最小風圧係数に及ぼす移動平均並びに空間平均 の影檽

(Effects of time and spatial averaging on the minimum pressure coefficient)

ている。屋根䧉角部の $C_{p, \min }(0) / C_{p, \min }(0)$ に及ぼす $A$ の影霎に関しては丸田ら ${ }^{84)}$ も検討しているが, 彼らの 結果（図中の口印）も筆者らの結果とよく一致してい る。さらに, 実線はカナタ規準 ${ }^{85)}$ を表している。これ を風洞実䄼結果と比較すると, 規準值はいくらか安全側 の設定になっているようである。

建築外装材には様々なものが用いられ，その形状や寸 法もまちまちである。設計用外圧係数は, 本来外装材の 荷重負担面積を適切に考虚して設定されるべきもので ある。ピーク風圧の評価時間についても同様である。上 述のように, 外装材の荷重負担面積とピークの評価時間 を結びっける為には, 変動風圧力のルートコヒーレンス に関する情報か必要である。 $k_{p}$ の值は一般に建物形状 や部位によって変化するが,これまで $k_{p}$ に関する研究 はあまり為されていない。今後, 各種形状および各部位 について, $k_{p}$ に関するデータの蓄積が望まれる。

\section{5. 建物形状と風圧係数}

建物の強風被害調查によれば, 同一地域でも建物（特 に, 屋根) 形状によって被害程度が異なり,一般には切 妻屋根より寄棟屋根の方が被害は軽微である。屋根形 状が変われば作用する風圧力の大きさや分布が異なる のは当然であるが, 屋根の封風性は風荷重だけではなく 構造耐力の面からも論じられなければならない。北米 では切妻および寄棟屋根の構造としてFig. 8に示すよ うなものがよく用いられる ${ }^{65)}$ 。Fig. 9は, 屋根勾配が4: 12 の低首建築物 $(B \times L=10 \mathrm{~m} \times 20 \mathrm{~m}, h=3 \mathrm{~m})$ に
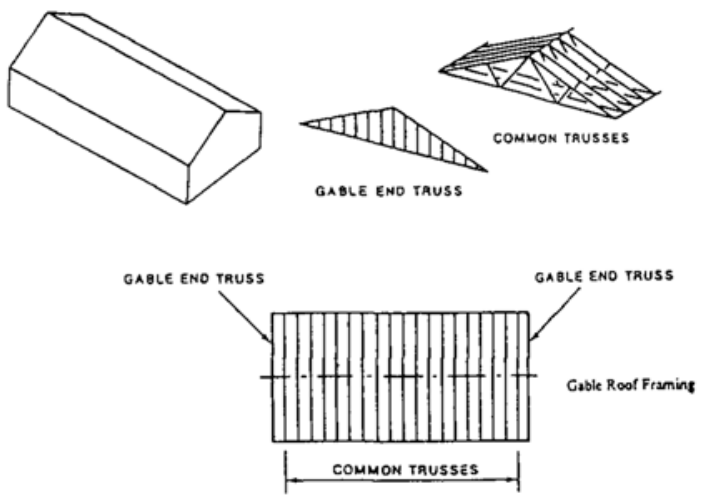

(a) 切妻屋根

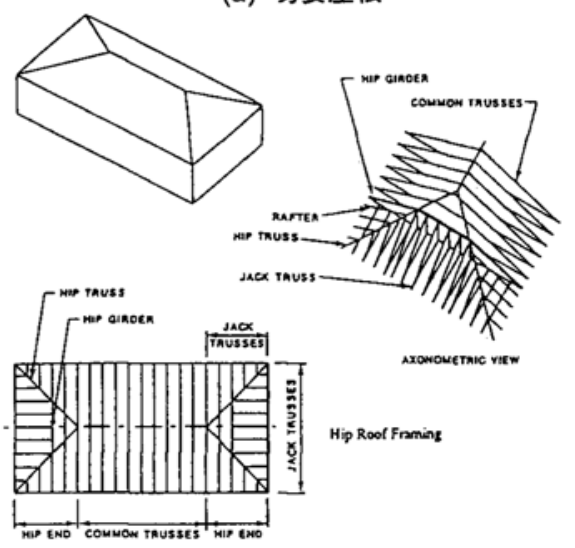

(b) 寄棟屋根

Fig. 8 北米での切妻屋根と寄棟屋根の一般的構法 ${ }^{65)}$ (Structural framing of hip and gable roofs used in North America ${ }^{65}$ )

対し, 風向角 $\theta=90^{\circ}$ に対する平均風圧係数分布を示 す ${ }^{65)}$ 。困中の実線は標準的なトラス位置を表わしてい

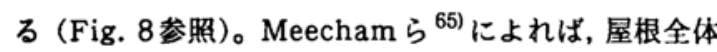
に作用する揚力や転倒モーメントはいずれの屋根の場 合もほぼ同じである。しかし, 最も風上側のトラス梁に 作用する風力に着目すると，切妻屋根の場合には，風圧 係数が大きいだけでなくトラス梁の荷重負担領域内て の風圧力の相関が高いので, 大きなピーク風力が発生す る。一方, 寄棟屋根の場合には, 風圧係数が小さく風圧 力の相関も低くなるので, 切妻屋根に比べてピーク風力 が低下し，最大ピーク風力（上向き）の大きさは切妻屋 根の值の $1 / 2$ 以下にもなる。

切妻および寄棟以外の屋根形状に関しても，いくつか の実検的研究が為されている。例えば, Blessmann ${ }^{86}$ は負勾配の屋根 (M 形屋根) について, Stathopoulos \& Mohammadian ${ }^{87)}$ は片流れ屋根について調へ, 切妻 
屋根の結果と比較した。さらに, Stathopoulos \& Saathoff ${ }^{88)-90)}$ は, 鋁形屋根 (等辺および片流れ) の平 均・ピーク風圧俰数を測定し, 風向が棟に直角の場合, オーストラリア基準值 ${ }^{91)}$ より一般に大きくなることを 示した。

屋根全体の形状を変えなくても种の形を変えること によって屋根荷重を低娍することが可能である。例え ば, Blackmore ${ }^{92)}$ は，軒の角を落とす（面取りをする）

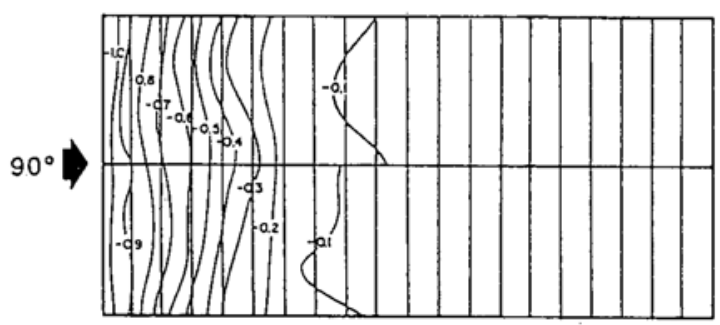

(a) 切妻屋根

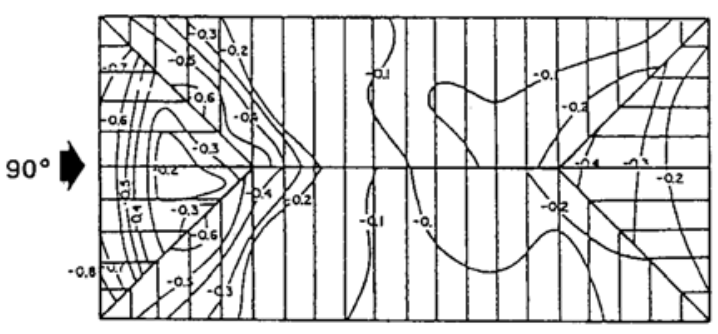

(b) 寄棟屋根

Fig. 9 切妻屋根および寄棟屋根の平均風圧係数分布 ${ }^{65)}$ (Mean pressure coefficient contours superimposed on structural framing ${ }^{65)}$ )
ことによって, 陸屋根隅角部のパネル領域に作用する風 圧力を最大 $70 \%$ まで, 屋根面全体風力を最大 $30 \%$ まで 低減できることを示した。これは，軒形状の変化によっ て剥崔泡が小さくなり，高負圧領域が縮小すると共に風 上端での渦形成が抑制されるためである。このように, 陸屋根の場合, 剥部泡の箖小は屋根面全体風力の低減に 大きな奻果をもたらす。軒形状を丸くしても同様の効 果が期待される。Robertson ${ }^{22)}$ おびHoxey ${ }^{31)}$ は, Silsoe Structures Buildingにおいて, 形状を丸くした時 の屋根面上圧力分布の変化を調へた。 $\theta=0^{\circ}$ の場合に ついて, 中央断面内の平均風圧係数分布を Fig. 10 に示 す。杆形状を丸くすると (図中のの印)，軒位置での流 れの剥崔は発生しなくなり, 風上端部の局部風圧は著し く低下することが分かる。しかし，棟近傍の領域では逆 に負圧が大きくなっている。従って,この建物のような 勾配屋根の場合, 形形の変化は風上端部の局部風圧を 大きく低娍する奻果はあるか，梁全体に作用する揚力に 対してはそれほど大きな奻果をもたらさないといえる。

陸屋根の埸合, 軒形状の変化のほか, パラペットも局 部風圧の低娍に有効である。これは, 剥離せん断層を屋 根面位置から㫿し, 剥麖によって生じる大きな局部風圧 を広籍囲に拡散させるからである。パラペットの効果 はその高さ $h_{p}$ と屋根高さ $H$ との比 $\left(h_{p} / H\right)$ で表され, Kind ${ }^{75)}$ によれば, 斜め方向からの風に対して用角部に 発生する最大ピーク負圧は $h_{p} / H$ の增大に伴って単調に 減少する。しかし, パラペットを付けると, 大きなピー ク負圧の発生領軽が広がるため, 面平均風圧力は逆に增 大する場合もある。さらに, パラペットの高さだけでな

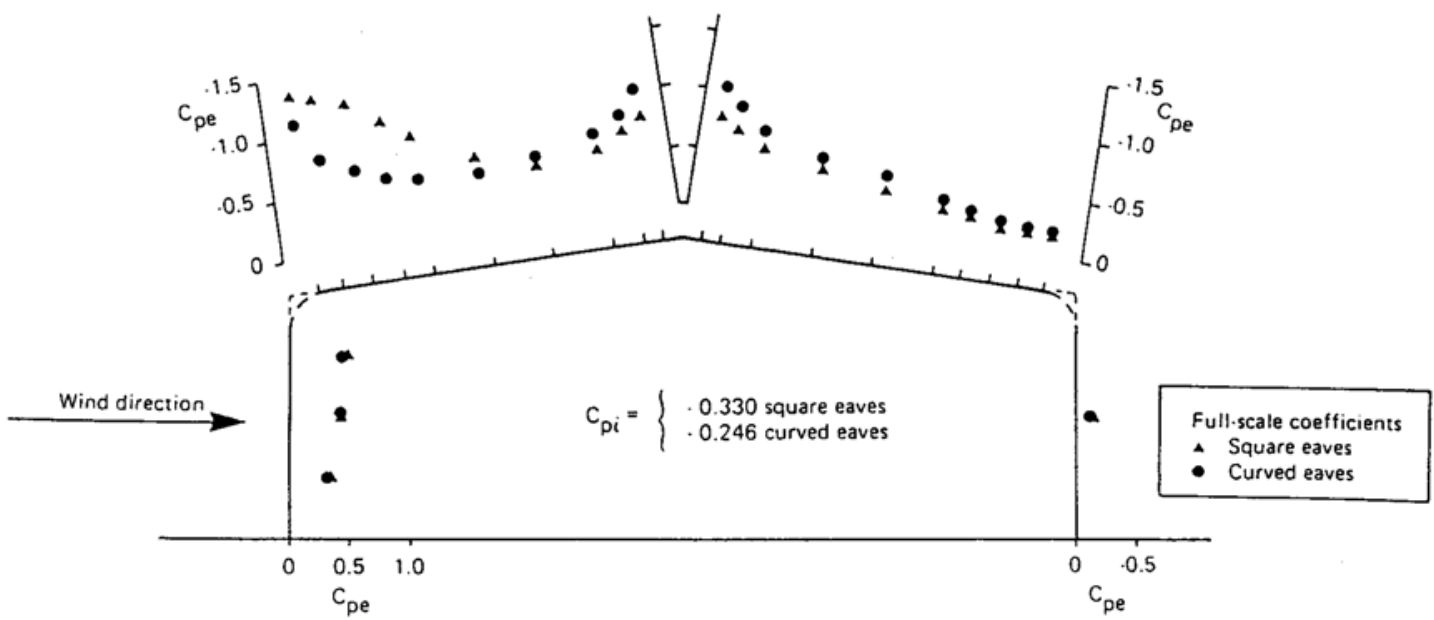

Fig. 10 軒形状の変化による平均風圧係数分布の変化 ${ }^{31)}$ (Distributions of the mean pressure coefficient for square and curved eaves ${ }^{31}$ ) 
くその形状が屋根面風圧性状に及ぼす影霓については, Baskaran \& Stathopoulos ${ }^{93)}$ が風洞実験によって検 討している。これは, 隅角部のパラペット形状を工夫す ろことによって, 強い円錐渦の生成を抑制し, 大きなピー ク負圧の発生を防ごうというものである。同様の発想 で, Cochran ら ${ }^{94)}$ は屋根隅角部にスクリーンを設置す ると渦の強さが低下することに着目し、スクリーンの形 状や充実率の影管を風洞実澞によって調へている。ま た, Surry \& Lin ${ }^{95)} も$ 屋根㭷角部に取り付けられた付 属物 (三角形板, 半円简形突起物, 放射状のスブリッタ 板, 多孔性のパラペット) の効果を風洞実験で恰討した。 その結果, 多孔性のパラペットが最も効果的であると述 ベている。

\section{6. おわりに}

本詥文は、筆者らの研究も含め, 既往の風洞実矣や実 測結果を比較・検討したものである。また, 特徽的な結 果については，適宜困を引用しなから説明した。多くの 実験結果は低居建築物の風荷重評価におけるピークフ フクター法の有用性を示唆している。また，その基碳と なるrms変動風圧係数の評価においては, 洀定常アプロー チが有効であることも示され, 筆者らがこれまで提案し た簡便な風荷重算定法の妥当性が確梕された。

前述したように, 近年自然風中での実測的研究が精力 的に行われ，接地境界首や低首建築物に作用する風圧力 の特性が明らかになってきた。またそれれらの詰果がべ ンチマークとなって妥当な風洞実験手法についても詳 細に検討されてきた。しかし，詳細な検討が行われた建 物形状は依然として限られたものである。低屏建築物 の形状は多種多様であり, 今後様々な形状に関するデー 夕の蓄積が望まれる。幸いにして, 準定常アプローチに よる荷重評価が概ね妥当であることより, 先ずは平均風 圧係数に関する情報の蓄積が有効であろう。

本研究の一部は、筆頭著者が平成 7 年度文部省派遗在 外研究員として1996年3月〜8月の6ヶ月間, カナタの ウェスタンオンタリオ大学・BLWTLおよびドイッの ルール大学に带在した㿟に行なったものである。

論文の収集・整理に祭しては, (株) 大林組の三吉举 志氏 (元東北大学大学院生) より協力を得た。ここに 記し, 感謝の意を表する。

\section{考文献}

1 Y. Uematsu and N. Isyumov: Wind pressures acting on the roof and wall edges of a lowrise building Part 1 Characteristics of pressure distributions, Journal of Wind Engineering, JAWE, 70 (1997) 3-14.

$2 \mathrm{Y}$. Uematsu and $\mathrm{N}$. Isyumov : Wind pressures acting on the roof and wall edges of a lowrise building Part 2 Statistical properties of fluctuating pressures, Journal of Wind Engineering, JAWE, 72 (1997) 11-19.

3 Y. Uematsu and $\mathrm{N}$. Isyumov : Wind pressures acting on the roof and wall edges of a lowrise building Part 3 External pressure coefficients for cladding design, Journal of Wind Engineering, JAWE, 73 (1997) 15-24.

4 T. Stathopoulos: Wind loads on low-rise buildings: a review of the state of the art, Eng. Struct., 6 (1984) 119-135.

5 J.D. Holmes : Wind loads on low-rise building - a review, CSIRO, Division of Building Research, Hignett, Victoria, Australia, 1993.

6 P. Krishna : Wind loads on low rise buildings - a review, J. Wind Eng. Ind. Aerodyn., 54 /55 (1995) 383-396.

7 M. Kasperski : Design wind loads for lowrise buildings: a critical review of wind load specifications for industrial buildings, J. Wind Eng. Ind. Aerodyn., 61 (1996) 169179.

8 植松 康, 三吉举志, 佐々木和彦, 山田大彦: 台風に よる住宅外装材の強風災害について一東北地方を対 象とした実被害调査結果一, 東北地域災害研究, 34 (1998) 155-164.

9 P.R. Sparks, S.D. Schiff and T.A. Reinhold: Wind damage to envelopes of houses and consequent insurance losses, J. Wịnd Eng. Ind. Aerodyn., 53 (1994) 145-155.

10 K.J. Eaton and J.R. Mayne: The measurement of wind pressures on two-story houses at Aylesbury, J. Ind. Aerodyn., 1 (1975) 67-109.

11 K.J. Eaton, J.R. Mayne and N.J. Cook: Wind loads on low-rise buildings-effects of roof geometry, Proc. 4th Int. Conf. on Wind Effects 
on Buildings and Structures, 1975, Heathrow, (1977) 95-110.

12 B.L. Sill, N.J. Cook and C. Fang: The Aylesbury Comparative Experiment: a final report, J. Wind Eng. Ind. Aerodyn., 41-44 (1992) 1553-1564.

13 L. Apperley, D. Surry, T. Stathopoulos and A.G. Davenport : Comparative measurements of wind pressure on a model of the fullscale experimental house at Aylesbury, England, J. Ind. Aerodyn., 4 (1979) 207-228.

14 P.J. Vickery and D. Surry: The Aylesbury experiments revisited-further wind tunnel tests and comparisons, J. Wind Eng. Ind. Aerodyn., 11 (1983) 39-62.

15 A.E. Holdo, E.L. Houghton and F.S. Bhinder : Some effects due to variations in turbulence integral length scales on the pressure distribution on wind-tunnel models of lowrise buildings, J. Wind Eng. Ind. Aerodyn., 10 (1982) 103-115.

16 B.L. Sill, N.J. Cook and P.A. Blackmore: IAWE Aylesbury Comparative Experiment-preliminary results of wind tunnel comparisons, J. Wind Eng. Ind. Aerodyn., 32 (1989) 285-302.

17 S.O. Hansen and E.G. Sorensen: The Aylesbury experiment. Comparison of model and fullscale tests, J. Wind Eng. Ind. Aerodyn., 22 (1986) 1-22.

18 P.J. Vickery, D. Surry and A.G. Davenport : Aylesbury and ACE : some interesting findings, J. Wind Eng. Ind. Aerodyn., 23 (1986) 1-17.

19 S. Mousset: The international Aylesbury Collaborative Experiment in C.S.T.B., J. Wind Eng. Ind. Aerodyn., 23 (1986) 19-36.

20 G.M. Richardson, A.P. Robertson, R.P. Hoxey and D. Surry : Full-scale and model investigations of pressures on an industrial/ agricultural building, J. Wind Eng. Ind. Aerodyn., 36 (1990) 1053-1062.

21 G.M. Richardson and D. Surry : Comparisons of wind-tunnel and full-scale surface pressure measurements on low-rise pitched-roof buildings, J. Wind Eng. Ind. Aerodyn., 38 (1991)
249-256.

22 A.P. Robertson: Effect of eaves detail on wind pressures over an industrial building, J. Wind Eng. Ind. Aerodyn., 38 (1991) 325333.

23 E. Savory, N. Toy, S. Dalley and J. Trussler : Wind loading on a portal frame agricultural building, J. Wind Eng. Ind. Aerodyn., 38 (1991) $335-345$.

24 S. Dalley and G. Richardson: Reference static pressure measurements in wind tunnels, J. Wind Eng. Ind. Aerodyn., 41-44 (1992) 909 -920 .

25 G.M. Richardson and D. Surry : The Silsoe Building: a comparison of pressure coefficients and spectra at model and full-scale, J. Wind Eng. Ind. Aerodyn., 41-44 (1992) 1653-1664.

26 E. Savory, S. Dalley and N. Toy : The effects of eaves geometry, model scale and approach flow conditions on portal frame building wind loads, J. Wind Eng. Ind. Aerodyn., 41 -44 (1992) 1665- 1676.

27 R.P. Hoxey and P.J. Richards: Flow patterns and pressure field around a full-scale building, J. Wind Eng. Ind. Aerodyn., 50 (1993) 203212.

28 G.M. Richardson and D. Surry : The Silsoe Structures Buildings: comparison between full-scale and wind-tunnel data, J. Wind Eng. Ind. Aerodyn., 51 (1994) 157-176.

29 G.M. Richardson and P.A. Blackmore: The Silsoe Structures Building : comparison of $1: 100$ model-scale data with full-scale data, J. Wind Eng. Ind. Aerodyn., 57 (1995) 191201.

30 S. Dalley : Surface pressure spectra on a model of the Silsoe structures building and comparison with full-scale, J. Wind Eng. Ind. Aerodyn., 60 (1996) 177-187.

31 R.P. Hoxey : Structural response of a portal framed building under wind load, J. Wind Eng. Ind. Aerodyn., 38 (1991) 347-356.

32 A.P. Robertson: The wind-induced response of a full-scale portal framed building, J. 
Wind Eng. Ind. Aerodyn., 41-44 (1992) 1677 $-1688$.

33 R.P. Hoxey and A.P. Robertson: Pressure coefficients for low-rise building envelops derived from full-scale experiments, J. Wind Eng. Ind. Aerodyn., 53 (1994) 283-297.

34 G.M. Richardson, R.P. Hoxey, A.P. Robertson, and J.L. Short: The Silsoe Structures Building: the completed experiment Part 1, Proc. 9th Int. Conf. on Wind Eng., New Delhi, 1995, 3 (1995) 1103-1114.

35 R.P. Hoxey, P.J. Richards, G.M. Richardson, A.P. Robertson and J.L. Short: The Silsoe Structures Building : the completed experiment Part 2, Proc. 9th Int. Conf. on Wind Eng., New Delhi, 1995, 3 (1995) 1115-1126.

36 P.J. Richards, R.P. Hoxey and B.S. Wanigaratne : The effect of directional variations on the observed mean and rms pressure coefficients, J. Wind Eng. Ind. Aerodyn., 54/55 (1995) 359 $-367$.

37 R.P. Hoxey and P.J. Richards : Full-scale wind load measurements point the way forward, J. Wind Eng. Ind. Aerodyn., 57 (1995) 215224.

38 M.L. Levitan and K.C. Mehta: Texas Tech field experiments for wind loads part 1 : building and pressure measuring system, J. Wind Eng. Ind. Aerodyn., 41-44 (1992) 1565 $-1576$.

39 M. L. Levitan and K.C. Mehta : Texas Tech field experiments for wind loads part II : meteorological instrumentation and terrain parameters, J. Wind Eng. Ind. Aerodyn., 41 - 44 (1992) 1577- 1588.

40 B.B. Yeatts, K.C. Mehta and D.A. Smith : Field experiments for wind effects on low buildings, Proc. 9th Int. Conf. on Wind Eng., New Delhi, 1995, 1 (1995) 500-511.

41 M.L. Levitan, K.C. Mehta, W.P. Vann and J. D. Holmes : Field measurements of pressures on the Texas Tech Building, J. Wind Eng. Ind. Aerodyn., 38 (1991) 227-234.
42 K.C. Mehta, M.L. Levitan, R.E. Iverson and J.R. McDonald: Roof corner pressures measured in the field on a low building, J. Wind Eng. Ind. Aerodyn., 41-44 (1992) 181-192.

43 C.W. Letchford, R.E. Iverson and J.R. McDonald: The application of the Quasi-steady Theory to full scale measurements on the Texas Tech Building, J. Wind Eng. Ind. Aerodyn., 48 (1993) 111-132.

$44 \mathrm{C} . \mathrm{W}$. Letchford and K.C. Mehta: The distribution and correlation of fluctuating pressures on the Texas Tech Building, J. Wind Eng. Ind. Aerodyn., 50 (1993) 225-234.

45 D.A. Smith, K.C. Mehta, B.B. Yeatts and S. V. Bhavaraju: Area-averaged and internal pressure coefficients measured in the field, J. Wind Eng. Ind. Aerodyn., 53 (1994) 89103.

46 J.R. McDonald, P.P. Sarkar and H. Gupta : Wind-induced loads on metal edge flashings, Proc. 9th Int. Conf. on Wind Eng., New Delhi, 1995, 3 (1995) 1139-1150.

47 Y.L. Xu : Model- and full-scale comparison of fatigue-related characteristics of wind pressures on the Texas Tech Building, J. Wind Eng. Ind. Aerodyn., 58 (1995) 147- 173.

48 D. Surry: Pressure measurements on the Texas Tech Building : wind tunnel measurements and comparisons with full scale, J. Wind Eng. Ind. Aerodyn., 38 (1991) 235-247.

49 L.S. Cochran and J.E. Cermak : Full- and model-scale cladding pressures on the Texas Tech University experimental building, J. Wind Eng. Ind. Aerodyn., 41-44 (1992) 1589 -1600 .

$50 \mathrm{H}$. Okada and Y.C. Ha : Comparison of wind tunnel and full-scale pressure measurement tests on the Texas Tech Building, J. Wind Eng. Ind. Aerodyn., 41-44 (1992) 1601-1612.

51 A.W. Rofail : Full-scale/model-scale comparisons of wind pressures on the TTU Building, Proc. 9th Int. Conf. on Wind Eng., New Delhi, 1995, 3 (1995) 1055-1066. 
52 H.W. Tieleman, D. Surry and K.C. Mehta : Full/model-scale comparison of surface pressures on the Texas Tech experimental building, J. Wind Eng. Ind. Aerodyn., 61 (1996) $1-23$.

$53 \mathrm{H}$. W. Tieleman : Model/full scale comparison of pressures on the roof of the TTU experimental building, J. Wind Eng. Ind. Aerodyn., 65 (1996) 133-142.

54 H.W. Tieleman, T.A. Reinhold and M.R. Hajj : Importance of turbulence for the prediction of surface pressures on low-rise structures, J. Wind Eng. Ind. Aerodyn., 69-71 (1997) 515 $-528$.

55 J.C.K. Cheung, J.D. Holmes, W.H. Melbourne, N. Lakshmanan and P. Bowditch: Pressures on a $1 / 10$ scale model of the Texas Tech Building, J. Wind Eng. Ind. Aerodyn., 69-71 (1997) 529-538.

56 T.C. E. Ho, D. Surry and A.G. Davenport : The variability of low building wind loads due to surrounding obstructions, J. Wind Eng. Ind. Aerodyn., 36 (1990) $161-170$.

57 T.C.E. Ho, D. Surry and A.G. Davenport : Variability of low building wind loads due to surroundings, J. Wind Eng. Ind. Aerodyn., 38 (1991) 297-310.

58 T.C.E. Ho, D. Surry and A.G. Davenport : Low building wind load variability with application to codes, J. Wind Eng. Ind. Aerodyn., 41-44 (1992) 1787-1798.

59 日本建築学会 : 建築物荷重指針・同解説, 1993 .

60 T. Stathopoulos, D. Surry and A.G. Davenport : Effective wind loads on flat roofs, J. Struct. Div., ASCE, 107 (1981) 281-298.

61 A.G. Davenport: On the assessment of the reliability of wind loading on low buildings, J. Wind Eng. Ind. Aerodyn., 11 (1983) 21 37.

62 R.J. Kind : Worst suctions near edges of flat rooftops on low-rise buildings, J. Wind Eng. Ind. Aerodyn., 25 (1986) 31-47.

63 A.P. Robertson : Codification of local pressure coefficients for low-rise structures, J. Wind
Eng. Ind. Aerodyn., 30 (1988) $143-152$.

64 D. Surry : Recent and current research into wind loading of low rise buildings at The University of Western Ontario, J. Wind Eng. Ind. Aerodyn., 36 (1990) 1319-1329.

65 D. Meecham, D. Surry and A.G. Davenport : The magnitude and distribution of windinduced pressures on hip and gable roofs, J. Wind Eng. Ind. Aerodyn., 38 (1991) 257272.

66 B. Bienkiewicz and Y. Sun : Local wind loading on the roof of a low-rise building, J. Wind Eng. Ind. Aerodyn., 45 (1992) 11-24.

67 H.Kawai and G. Nishimura: Characteristics of fluctuating suction and conical vortices on a flat roof in oblique flow, J. Wind Eng. Ind. Aerodyn., 60 (1996) 211-225.

68 P.C. Case and N. Isyumov : The performance of wood buildings with $4: 12$ pitched roofs under extreme wind loads, BLWT-SS28-1995, The Univ. of Western Ontario, 1995.

69 H.J. Gerhardt and C. Kramer : Wind induced loading cycle and fatigue testing of lightweight roofing fixations, J. Wind Eng. Ind. Aerodyn., 23 (1986) 237-247.

70 H.J. Gerhardt and C. Kramer : Effect of building geometry on roof windloading, J. Wind Eng. Ind. Aerodyn., 41-44 (1992) 1765-1773.

71 B. Bienkiewicz, H.J. Ham and Y. Sun : Proper orthogonal decomposition of roof pressure, J. Wind Eng. Ind. Aerodyn., 50 (1993) 193202.

72 H. Kawai : Pressure fluctuations on square prisms-applicability of strip and Quasi-steady Theories, J. Wind Eng. Ind. Aerodyn., 13 (1983) 197-208.

73 T. Stathopoulos, D. Surry and A.G. Davenport : A simplified model of wind pressure coefficients for low-rise buildings, Proc. 4th Colloq. on Industrial Aerodynamics, Aachen, 1980.

74 T. Stathopoulos, D. Surry and A.G. Davenport : Some general characteristics of turbulent wind effects on low-rise structures, Proc. 3rd Colloq. on Industrial Aerodynamics, Aachen, 
1978, Buildings Aerodynamics, Part 1 (1978) 211-224.

75 R.J. Kind : Worst suctions near edges of flat rooftops with parapets, J. Wind Eng. Ind. Aerodyn., 31 (1988) 251-264.

76 R.V. Milford and J.L. Waldeck : Statistics of full-scale surface pressures, J. Wind Eng. Ind. Aerodyn., 30 (1988) 35-44.

77 H.W. Tieleman : Simulation of surface winds for assessment of extreme wind loads on roofs, Proc. 9th Int. Conf. on Wind Eng., New Delhi, 1995, 3 (1995) 1162-1169.

$78 \mathrm{~T}$. Stathopoulos: PDF of wind pressures on low-rise buildings, J. Struct. Div., ASCE, 106 (1980) 973-990.

79 J.D. Holmes : Non-Gaussian characteristics of wind pressure fluctuations, J. Wind Eng. Ind. Aerodyn., 7 (1981) 103-108.

80 N.J. Cook and J.R. Mayne: A novel working approach to the assessment of wind loads for equivalent static design, J. Ind. Aerodyn., 4 (1979) 149-164.

81 N.J. Cook and J.R. Mayne: A refined working approach to the assessment of wind loads for equivalent static design, J. Wind Eng. Ind. Aerodyn., 6 (1980) 125-137.

82 N.J. Cook : Calibration of the quasi-static and peak-factor approaches to the assessment of wind loads against the method of Cook and Mayne, J. Wind Eng. Ind. Aerodyn., 10 (1982) 315-341.

83 T.V. Lawson: Wind Effects on Buildings, Vol.1 Design Applications, Applied Science Publishers, 1980.

84 丸田栄藏, 上田 宏, 神田 亮: 切妻屋根の局部風圧 について, 日本大学生産工学部第 24 回学術講演会, 1991, pp.33-36.
85 The National Building Code of Canada National Research Council of Canada, 1990.

$86 \mathrm{~J}$. Blessmann: Wind pressures on roofs with negative pitch, J. Wind Eng. Ind. Aerodyn., 10 (1982) 213-230.

87 T. Stathopoulos and A.R. Mohammadian : Wind loads on low buildings with monosloped roofs, J. Wind Eng. Ind. Aerodyn., 23 (1986) 81-97.

88 T. Stathopoulos and P. Saathoff : Wind pressure on roofs of various geometries, J. Wind Eng. Ind. Aerodyn., 38 (1991) 273-284.

89 T. Stathopoulos and P. Saathoff : Codification of wind pressure coefficients for sawtooth roofs, J. Wind Eng. Ind. Aerodyn., 41-44 (1992) 1727-1738.

90 P.J. Saathoff and T. Stathopoulos: Wind loads on buildings with sawtooth roofs, J. Struct. Eng., ASCE, 118 (1992) 429-446.

91 Australian Standard, Minimum design loads on structures. Part 2: Wind Loads, AS1170. 2, 1989.

92 P.A. Blackmore: Load reduction on flat roofsthe effect of edge profile, J. Wind Eng. Ind. Aerodyn., 29 (1988) 89-98.

93 A. Baskaran and T. Stathopoulos: Roof corner wind loads and parapet configurations, J. Wind Eng. Ind. Aerodyn., 29 (1988) 79-88.

94 L.S. Cochran, J.E. Cermak and E.C. English, Load reduction by modifying the roof corner vortex, Proc. 9th Int. Conf. on Wind Eng., New Delhi, 1995, 3 (1995) 1091-1102.

95 D. Surry and J.X. Lin, The effect of surroundings and roof corner geometric modifications on roof pressures on low-rise buildings, J. Wind Eng. Ind. Aerodyn., 58 (1995) 113-138. 